\title{
The diversity of Odonata adults's at Pampa Biome from Brazil
}

\author{
Manoel D. N. Garcia Junior ${ }^{1}$, Matheus Rakes ${ }^{2 *}$, Juliano de B. Pazini², Rafael A. Pasini ${ }^{3}$,
} Flávio R. M. Garcia ${ }^{1} \&$ Anderson D. Grützmacher ${ }^{2}$

1. Department of Ecology, Zoology, and Genetics, Institute of Biology (IB), Federal University of Pelotas, postcode 96010-900, Pelotas, Rio Grande do Sul, Brazil; m.d.juniorbio@gmail.com, flaviormg@hotmail.com

2. Department of Plant Protection, Faculty of Agronomy "Eliseu Maciel” (FAEM), Federal University of Pelotas, postcode 96010-900, Pelotas, Rio Grande do Sul, Brazil; matheusrakes@hotmail.com, julianopazzini@hotmail.com, adgrutzm@ufpel.edu.br

3. Center for Higher Education Riograndense, postcode 99560000, Sarandi, Rio Grande do Sul, Brazil; rafaelpasini@cesurg.com.br

* Correspondence

\section{Received 14-V-2017. Corrected 25-XI-2018. Accepted 21-I-2019.}

\begin{abstract}
The growth of humankind has brought with it several environmental problems that have worsened over time, including the loss of insect biodiversity. The Odonata order have been indicated by several authors as relevant bioindicators for assessing and monitoring environmental conditions of specific locations. The main objective of this study was to conduct an inventory of the Odonata diversity in the Pampa Biome, of the Southern region of the state of Rio Grande do Sul, Brazil. The species survey was conducted between November 2014 and October 2015. Adult insects were collected in Capão do Leão, Pelotas and Rio Grande cities. Each location was visited nine times, totalizing 54 samplings. Entomological nets were used for capturing adult insects, which were then kept in entomological envelopes. The identification of the specimens was carried out with taxonomic keys of Lencioni and Heckman. In addition, Chao-1, the Shannon-Wiener and Jackknife indexes were associated with the sampling areas. During the species survey a total of 2680 Odonata specimens were collected, representing 45 species encompassed in 22 genera and six families. The Libellulidae and Coenagrionidae families were registered in 60 and $30 \%$ of the specimens sampled, followed of the Aeshnidae, Calopterygidae, Gomphidae and Lestidae, of reduced occurrence. The genera Erythrodiplax, Micrathyria and Ischnura were found at least once in all the visited sites. The study resulted in the registration for the first time of the following species: Progomphus complicatus Selys, Lestes minutus Selys, Homeoura ambigua Ris, and Tauriphila xiphea Ris. These species were not previously reported in any Odonata study of the Brazilian state of Rio Grande do Sul. In regard to Odonata diversity in the Southern region of Rio Grande do Sul, Libellulidae and Coenagrionidae are the families more abundants. Erythrodiplax and Micrathyria are the most common genera. Miathyria marcella represented $9.6 \%$ of all collected libellulidae and was the most abundant specie. Capão do Leão has the largest species diversity (wealth), the largest number of collected specimens and more diversity than Pelotas and Rio Grande. However, the results showed that the Odonatofauna in the State are still little known, and new studies are needed to better describe this group in other regions.
\end{abstract}

Key words: Insecta; biodiversity; Rio Grande do Sul; dragonflies; fauna indexes.

Garcia Junior, M. D. N., Rakes, M., Pazini, J. de B., Pasini, R. A., Flávio R. M. Garcia, F. R. M. \& D. Grützmacher, A. D. (2019). The diversity of Odonata adults's at Pampa Biome from Brazil. Revista de Biología Tropical, 67(1), 107-117.

Rio Grande do Sul (RS) State is located in the Southernmost territory of Brazil. It coverseveral regions and environments diversified climatic and geomorphologically. The Pampa Biome is located in the Southern of the state and is made up of a set of distinct ecosystems containing vast biodiversity. Although it remains mostly unexplored, this area consists of an extremely rich gene pool (Boldrini et al., 2010). 
These ecosystems have been affected by several human activities, such as inadequate use of the soil, inadequate disposal of industrial and domestic effluents, as well as the increasing use of agrochemicals (Esteves, 2011). This has contributed to biodiversity loss, jeopardizing the balance of aquatic and terrestrial biomes and, consequently, impacting human welfare (Cardinale et al., 2012). According to Merritt and Cummins (1996) invertebrates are one of the most common groups in freshwater environments, and, among them, insects stand out because of their association with other freshwater communities.

The Odonata order comprise insects commonly known as dragonflies, damselflies, lavabunda, zig-zag, and, specifically in Rio Grande do Sul, Cicadas. This order is composed of paleopterous amphibiotic insects, under hemimetabolous development, and is divided into three suborders: Zygoptera, Anisoptera and Anisozygoptera (Rehn, 2003). Globally, this order contains 6500 species (Trueman \& Rowe, 2009), and about 800 of them from 15 different families were reported in Brazil alone (Neiss \& Hamada, 2014).

These insects are relevant bioindicators for assessing and monitoring environmental conditions of specific locations. Thus, the greater the biodiversity, the better the health of that ecosystem (Ferreira-Peruquetti \& De Marco, 2002; Foote \& Rice, 2005; Silva, Marco, \& Resende, 2010; Carvalho, Silva-Pinto, Oliveira-Júnior, \& Juen, 2013; Monteiro Júnior, Couceiro, Hamada, \& Juen, 2013). In this context, some researchers have recognized the need to list the diversity of these animals and develop models and criteria that can be applied in environmental change assessments (Reaka-Kudla, Wilson, \& Wilson, 1997).

Species inventories are indispensable in management and conservation processes, in which the entomofauna diversity is an important tool for environmental sanity. Furthermore, the knowledge of insect diversity may provide valuable information on the integrity of the studied environments (Lutinski \& Garcia, 2005).
According to the Red List of Threatened Species of the International Union for Conservation of Nature (IUCN), one in ten Odonata species is in critical danger of being extinct (Mace et al., 2008), and $35 \%$ of them species lack incidence data (Clausnitzer et al., 2009). In Rio Grande do Sul (RS), there are very few studies that address the Odonata inventory and are limited almost exclusively to the reports made by Costa (1971) and Teixeira (1971) in Santa Maria and Porto Alegre cities, respectively. The last data concerning Odonato fauna in RS are present in the work of Kittel and Engels (2014), who studied the diversity of Zygotera in São Francisco de Paula. They included four new species in the list of registered species of the State. Furthermore, Renner, Périco, Sahlén, Dos Santos, and Consatt (2015) conducted an inventory study in 12 cities of the Rio Taquari valley region, where 50 Odonata species were found.

This study aims to widen the knowledge on the Odonata species and measure the species incidence in the aforementioned region. In addition, fauna indexes will be associated with the sampling areas.

\section{MATERIALS AND METHODS}

Field of study: Known as the "Southern fields", the Pampa Biome covers approximately $62 \%$ of Rio Grande do Sul $\left(177767 \mathrm{~km}^{2}\right)$ along with part of Argentina and the entire territory of Uruguay, which is rich in water resources. Most of the water bodies are ecologically classified as shallow lakes, which are easily influenced by natural and human activity because of their shallow depth (Trindade, Furlanetto, \& Silva, 2009; Zambrano, Contreras, Hiriart, \& Arista, 2009). The sampling areas are located in the Lagoa Mirim and Lagoa dos Patos, both lakes with well defined seasons with cold and rainy winters and hot and dry summers. According to the Köppen-Geiger climate classification, local climate is considered $\mathrm{Cfa}$ (humid subtropical). In this region, average annual temperature varies between $16{ }^{\circ} \mathrm{C}$ and 
$18{ }^{\circ} \mathrm{C}$ and average annual rainfall is approximately $1500 \mathrm{~mm}$.

In the cities where the study was conducted, two collection sites were selected with three sampling points each. In Capão do Leão, sampling was conducted at Campus of the Federal University of Pelotas - UFPel (31 ${ }^{\circ} 80^{\prime} 16^{\prime \prime}$ S - 52 41'94” W) and at Irmão Teodoro Luis

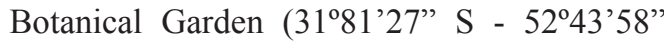
W). In Pelotas, the samples were collected in Vila Princesa $\left(31^{\circ} 62^{\prime} 79^{\prime \prime} \mathrm{S}\right.$ - 52 $32^{\prime} 66^{\prime}$ " W) and Balneário dos Prazeres (31 ${ }^{\circ} 72^{\prime} 07^{\prime}$ ' S - 52 $2^{\circ} 19^{\prime} 14^{\prime \prime}$ W). In Rio Grande city, the samples collected in Arroio Bolaxa ( $32^{\circ} 16^{\prime} 02^{\prime \prime}$ $\left.\mathrm{S}-52^{\circ} 18^{\prime} 80^{\prime \prime} \mathrm{W}\right)$ and Taim Ecological Station (32 44'33" S - 52 34'28" W).

Collected data: Odonata samples were obtained between November 2014 to October 2015; no samples were taken during the winter season because of the lack of activity among adult insects due to low temperatures. Each location was visited nine times, totalizing 54 samplings. In order to capture the insects, the active collection method was conducted with entomological nets. The samplings were performed on sunny days, between 9 am to $4 \mathrm{pm}$, during a period of three hours at each collection site.

Species identification: The collected specimens were kept alive in entomological envelopes for at least four hours and were later treated with Acetone, as methodology proposed by Lencioni (2005). Samples were identified using the taxonomic keys proposed by Lencioni $(2005 ; 2006)$ and Heckman (2006; 2008). Damaged especimens or those that had no similarity with the descriptions offered in literature were classified at generic level. The specimens were deposited at the Ceslau Biezanko Entomological Museum, UFPEL.

Data analysis: The data analyses were conducted considering specific abundance (n), generating the species-accumulation curve. Relative frequency (Rf) was measured by dividing the total number of collected species by the total of collected insects, multiplied by 100 (Silveira Neto, Nakana, Barbin, \& Vila Nova, 1976; Bianconi, Mikich, \& Pedro, 2004). For this measurement, a $5 \%$ confidence interval was used, and species were classified as very frequent $(\mathrm{C} \geq 50 \%)$, frequent $(25 \% \leq$ $\mathrm{C}<50 \%)$ and infrequent $(\mathrm{C}<25 \%)$.

The abundance assessments and comparisons were conducted using the Chao-1 estimator. Based on abundance, this evaluation relates the number of species represented by only one individual (singletons), and the number of species with only two sample individuals (doubletons) (Colwell, 2012). Furthermore, it is calculated by the equation: Chao $1=\mathrm{S}+$ $\left(\mathrm{a}^{2} / 2 \mathrm{~b}\right)$; in which $S$ is the number of encountered species in the samples, $a$ is the number of species represented by one specimen, and $b$ is the number of species represented by two specimens (Chao, 1984; 1987; Ferraz, Gadelha, \& Aguiar-Coelho, 2009).

The diversity measurement was performed using the Shannon-Wiener index: $\mathrm{H}^{\prime}=-\Sigma(f i)$ $\log (f i)$; in which $f i$ is the proportion of individuals belonging to the $\mathrm{n}^{\text {th }}$ specie and $\ln$ is the neperian logarithm (Pielou, 1975).

For the species-diversity estimates and their confidence intervals (95\%), the analytical estimator first-order Jackknife index was used (Jack $1=\mathrm{S}+\mathrm{L}(\mathrm{n}-1 / \mathrm{n})$, in which $\mathrm{S}$ is the sum of the species found in the samples, $\mathrm{L}$ is the number of species present in a single sample, and $\mathrm{n}$ is the total number of samples (Palmer, 1991). For calculations and graph and table elaboration, Excel and EstimateS 8.0 programs were used.

\section{RESULTS}

Considering all our sample collections, 2680 specimens were found, comprised by 45 species distributed into 22 genera and 6 families (Table 1). The species Progomphus complicatus, Lestes minutus, Homeoura ambigua and Tauriphila xiphea were recorded for the first time, in ascending order of frequency, in RS (Table 1). 
TABLE 1

List of the species collected in the Brazilian Pampa Biome (Southern region of Rio Grande do Sul) divided by suborder and families

\begin{tabular}{|c|c|c|c|c|c|c|c|c|c|}
\hline \multirow{2}{*}{$\begin{array}{l}\text { Family / Species } \\
\text { Suborder Zygoptera }\end{array}$} & \multicolumn{6}{|c|}{ Collection Sites ${ }^{1}$} & \multirow{2}{*}{ Total } & \multirow{2}{*}{$\%$} & \multirow{2}{*}{$\mathrm{Fr}^{2}$} \\
\hline & PBP & PVP & CHB & $\mathrm{CCL}$ & RAB & RET & & & \\
\hline \multicolumn{10}{|l|}{ Calopterygidae } \\
\hline Hetaerina rosea Selys, 1853 & 5 & 9 & 0 & 3 & 2 & 0 & 19 & 0.671 & IF \\
\hline \multicolumn{10}{|l|}{ Coenagrionidae } \\
\hline Acanthagrion gracile Rambur, 1842 & 2 & 1 & 0 & 1 & 2 & 0 & 6 & 0.223 & IF \\
\hline Acanthagrion lancea Selys, 1876 & 0 & 0 & 0 & 3 & 1 & 0 & 4 & 0.149 & IF \\
\hline Homeoura chelifera Selys, 1876 & 0 & 26 & 48 & 23 & 10 & 26 & 133 & 4.964 & VF \\
\hline Homeoura ambígua Ris, 1904* & 7 & 2 & 2 & 4 & 0 & 0 & 15 & 0.559 & IF \\
\hline Ischnura capreolus Hagen, 1861 & 36 & 26 & 41 & 47 & 29 & 40 & 219 & 8.137 & VF \\
\hline Ischnura fluviatilis Selys, 1876 & 41 & 29 & 29 & 56 & 30 & 39 & 224 & 8.361 & VF \\
\hline Oxyagrion terminale Selys, 1876 & 10 & 0 & 0 & 9 & 0 & 5 & 24 & 0.895 & IF \\
\hline Oxyagrion simile Costa, 1978 & 0 & 0 & 0 & 5 & 0 & 0 & 5 & 0.186 & IF \\
\hline Telebasis willinki Fraser, 1948 & 44 & 19 & 24 & 36 & 15 & 45 & 183 & 6.830 & VF \\
\hline \multicolumn{10}{|l|}{ Lestidae } \\
\hline Lestes undulatus Say, 1839 & 8 & 10 & 0 & 9 & 8 & 0 & 35 & 1.306 & IF \\
\hline Lestes tricolor Erichson, 1848 & 7 & 11 & 0 & 0 & 9 & 0 & 27 & 1.007 & IF \\
\hline Lestes minutus Selys, $1862 *$ & 0 & 0 & 0 & 0 & 0 & 8 & 8 & 0.298 & IF \\
\hline \multicolumn{10}{|l|}{ Suborder Anisoptera } \\
\hline \multicolumn{10}{|l|}{ Aeshnidae } \\
\hline Coryphaeschna amazonica DeMarmels, 1989 & 4 & 0 & 5 & 1 & 0 & 1 & 11 & 0.410 & IF \\
\hline Remartinia luteipennis Burmeister, 1839 & 0 & 6 & 3 & 4 & 5 & 0 & 18 & 0.671 & IF \\
\hline Rhionaeschna bonariensis Rambur, 1842 & 11 & 18 & 10 & 22 & 9 & 19 & 89 & 3.322 & $\mathrm{~F}$ \\
\hline Rhionaeschna cornigera Brauer, 1865 & 0 & 0 & 6 & 11 & 0 & 0 & 17 & 0.634 & IF \\
\hline \multicolumn{10}{|l|}{ Gomphidae } \\
\hline Progomphus complicatus Selys, 1854* & 0 & 6 & 0 & 0 & 0 & 0 & 6 & 0.223 & IF \\
\hline Phyllocycla sp. Calvert, 1948 & 0 & 0 & 0 & 7 & 0 & 0 & 7 & 0.261 & IF \\
\hline \multicolumn{10}{|l|}{ Libellulidae } \\
\hline Diastatops Intensa Montgomery, 1940 & 0 & 3 & 0 & 4 & 2 & 0 & 9 & 0.335 & IF \\
\hline Erythemis attala Selys in Sagra, 1857 & 0 & 23 & 18 & 22 & 15 & 41 & 119 & 4.441 & VF \\
\hline Erythemis plebeja Burmeister, 1839 & 0 & 7 & 4 & 16 & 8 & 10 & 45 & 1.679 & $\mathrm{~F}$ \\
\hline Erythemis peruviana Rambur 1842 & 0 & 35 & 20 & 30 & 13 & 7 & 105 & 3.919 & $\mathrm{~F}$ \\
\hline Erythemis vesiculosa (Fabricius, 1775) & 0 & 0 & 1 & 5 & 0 & 4 & 10 & 0.373 & IF \\
\hline Erythrodiplax fusca Rambur, 1842 & 21 & 16 & 9 & 31 & 10 & 30 & 117 & 4.367 & VF \\
\hline Erythrodiplax nigricans Rambur, 1842 & 0 & 18 & 0 & 24 & 0 & 2 & 44 & 1.642 & $\mathrm{~F}$ \\
\hline Erythrodiplax paraguayensisFörster, 1904 & 5 & 0 & 3 & 7 & 4 & 2 & 21 & 0.783 & IF \\
\hline Erythrodiplax atroterminata Ris, 1911 & 30 & 20 & 27 & 28 & 12 & 33 & 150 & 5.559 & VF \\
\hline Erythrodiplax chromoptera Borror, 1942 & 0 & 0 & 0 & 7 & 4 & 0 & 11 & 0.410 & IF \\
\hline Erythrodiplax media Borror, 1942 & 14 & 38 & 32 & 20 & 29 & 23 & 156 & 5.823 & VF \\
\hline Erythrodiplax hyalina Förster, 1907 & 10 & 6 & 8 & 19 & 1 & 5 & 49 & 1.829 & $\mathrm{~F}$ \\
\hline Erythrodiplax sp. Brauer, 1868 & 1 & 2 & 4 & 3 & 1 & 1 & 12 & 0.485 & IF \\
\hline Miathyria marcella Selys in Sagra, 1857 & 28 & 58 & 40 & 31 & 27 & 75 & 259 & 9.667 & VF \\
\hline Micrathyria tibialis Kirby, 1897 & 0 & 0 & 2 & 1 & 0 & 1 & 4 & 0.149 & IF \\
\hline Micrathyria hypodidyma Calvert, 1906 & 33 & 51 & 39 & 30 & 30 & 22 & 205 & 7.652 & VF \\
\hline Micrathyria pseudeximia Westfall, 1992 & 8 & 23 & 10 & 9 & 17 & 14 & 81 & 3.023 & $\mathrm{~F}$ \\
\hline Micrathyria stawiarskii Santos, 1953 & 0 & 0 & 4 & 1 & 1 & 2 & 8 & 0.289 & IF \\
\hline
\end{tabular}


TABLE 1 (Continued)

\begin{tabular}{|c|c|c|c|c|c|c|c|c|c|}
\hline \multirow{2}{*}{$\begin{array}{l}\text { Family / Species } \\
\text { Suborder Zygoptera }\end{array}$} & \multicolumn{6}{|c|}{ Collection Sites ${ }^{1}$} & \multirow{2}{*}{ Total } & \multirow{2}{*}{$\%$} & \multirow{2}{*}{$\mathrm{Fr}^{2}$} \\
\hline & PBP & PVP & $\mathrm{CHB}$ & CCL & RAB & RET & & & \\
\hline Micrathyria catenata Calvert, 1909 & 0 & 2 & 0 & 5 & 1 & 0 & 8 & 0.289 & IF \\
\hline Orthemis nodiplaga Karsch, 1891 & 1 & 8 & 0 & 16 & 9 & 12 & 46 & 1.717 & $\mathrm{~F}$ \\
\hline Orthemis ambinigra Calvert, 1909 & 3 & 5 & 0 & 2 & 3 & 6 & 19 & 0.709 & IF \\
\hline Pantala flavescens Fabricius, 1798 & 0 & 13 & 0 & 8 & 17 & 9 & 47 & 1.754 & $\mathrm{~F}$ \\
\hline Perithemis mooma Kirby, 1889 & 2 & 9 & 1 & 5 & 7 & 3 & 27 & 1.007 & IF \\
\hline Tauriphila risi Martin, 1896 & 12 & 4 & 0 & 8 & 11 & 6 & 41 & 1.530 & $\mathrm{~F}$ \\
\hline Tauriphila xiphea Ris, 1913* & 0 & 6 & 0 & 3 & 2 & 12 & 23 & 0.858 & IF \\
\hline Tramea cophysa Hagen, 1867 & 2 & 5 & 0 & 3 & 1 & 3 & 14 & 0.522 & IF \\
\hline Total & 345 & 515 & 390 & 579 & 345 & 506 & 2680 & 100 & \\
\hline Total by County & \multicolumn{2}{|c|}{860} & \multicolumn{2}{|c|}{969} & \multicolumn{2}{|c|}{851} & & & \\
\hline
\end{tabular}

${ }^{1}$ Pelotas, Balneário dos Prazeres (PBP) and Vila Princesa (PVP). Capão do Leão, Irmão Teodoro Luis Botanical Garden (CHB) and Capão do Leão Campus of the Federal University of Pelotas- UFPel (CCL). Rio Grande Arroio Bolaxa (RAB) and TAIM Ecological Station (RET). ${ }^{2}$ Frequency was indicated as follows: infrequent (IF), frequent (F) and very frequent (VF).*Newly-reported species in RS.

The most speciose genera were Erythrodiplax and Micrathyria, with eight and five species, respectively. These genera, represented by two species (Rhionaeschna bonariensis and Telebasis willinki), along with Ischnura, were found at least once in all the visited sites. Gomphidae specimens were less frequent and exhibited low density in this study, since $P$. complicatus specimens were found only in Pelotas, specifically on sandbanks of Arroio Pelotas, located in Vila Princesa. Female Phyllocycla were collected close to the pools of UFPel Campus in Capão do Leão (Table 1).

Ten species, from the Libellulidae (6) and Coenagrionidae (4), were considered very frequent (VF), reaching a total of $65 \%$ of the captured individuals. The Gomphidae and
Calopterygidae were represented by 32 total specimens, corresponding to $1.19 \%$ of the collected insects and considered infrequent (IF) (Table 1).

The Libellulidae family was the most abundant since it comprising $57.78 \%$ of the samples (Table 2), in which Miathyria marcella was the most common specie, amounting to $9.66 \%$ of total dragonfly samples (Table 1). The next most common families were Coenagrionidae and Aeshnidae, with a total of 20 $\%$ and $8.89 \%$ of the specimens, respectively. Lastly, the least abundant families were Lestidade with $6.67 \%$, Gomphidae with $4.44 \%$, and Calopterygidae with $2.22 \%$ of the sampled species. Concerning the sample density, the Libellulidae family comprised $60.82 \%$ of total

TABLE 2

Number of Odonata species collected in the the Brazilian Pampa Biome (Southern region of Rio Grande do Sul) from each family, their percentage (\%) in relation to the total of collected species and to the total of collected specimens

\begin{tabular}{llccc}
\multicolumn{1}{c}{ Suborder } & \multicolumn{1}{c}{ Family } & Number of species & Percentage (\%) & Density (\%) \\
Zigoptera & Coenagrionidae & 9 & 20.00 & 30.35 \\
& Lestidae & 3 & 6.67 & 2.61 \\
\multirow{5}{*}{ Anisoptera } & Calopterygidae & 1 & 2.22 & 0.70 \\
& Libellulidae & 26 & 57.78 & 60.82 \\
& Aeshnidae & 4 & 8.89 & 5.03 \\
Total & Gomphidae & 2 & 4.44 & 0.49 \\
\hline
\end{tabular}


TABLE 3

Fauna data analyses of the species collected in all three cities in the Brazilian Pampa Biome

\begin{tabular}{lccc}
\multicolumn{1}{c}{ Faunistic indexes } & Capão do Leão & Pelotas & Rio Grande \\
Individuals (n) & 969 & 860 & 851 \\
Species diversity & 42 & 36 & 40 \\
Shannon-Wiener (H') & 1.62 & 1.49 & 1.54 \\
Chao -1 & 46.3 & 48.6 & 48.0 \\
\hline
\end{tabular}

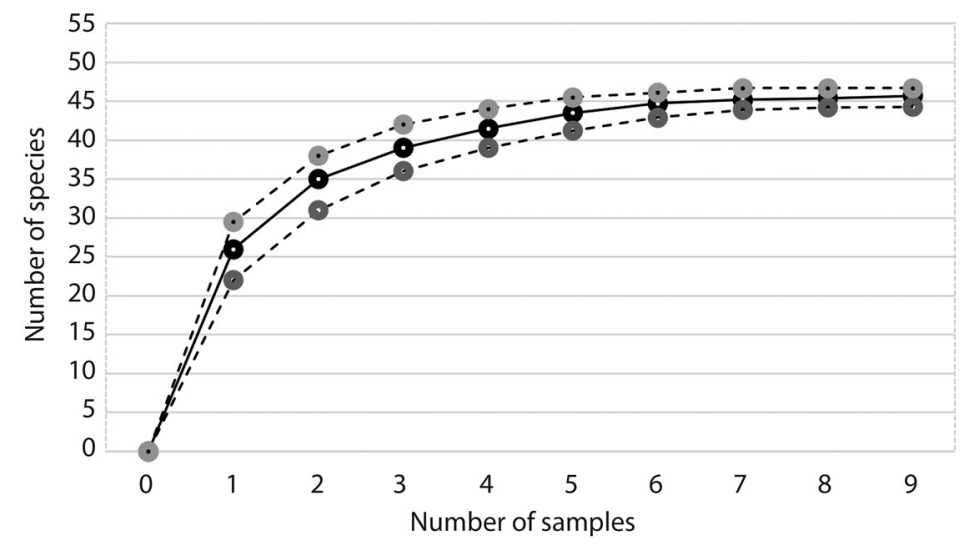

Fig. 1. The species accumulation curve of Odonata using the Jackknife index (Jack 1) in the Brazilian Pampa Biome The dashed lines represent the confidence interval (CI 95).

collected specimens, followed by Coenagrionidae of the Zigoptera suborder at $30.35 \%$ of total collected Odonata (Table 2).

Based on the different faunistc indexes (faunistic) (Table 3), the highest number of specimens were collected in Capão do Leão, followed by Pelotas, and Rio Grande, with 969,860 , and 851 specimens respectively. In addition, the highest specific wealth was also found at Capão do Leão, where 42 species were reported, while in Rio Grande and Pelotas 40 and 36 species were collected, respectively.

In the current study, the highest ShannonWiener diversity indexes were found in Capão do Leão (1.62) and Rio Grande (1.54), while Pelotas (1.49) exhibited the lowest result. On the other hand, regarding the species-diversity estimator, Chao 1 method, Pelotas reached the highest value, followed by Rio Grande (48.0) and Capão do Leão (46.3) (Table 3).

The species accumulation curve (Fig. 1) was unable to reach the asymptote, indicating that the diversity in the region is relatively larger than the 45 species found in the current study. The first-order Jackknife index is 57.3 species, with standard deviation of \pm 8.2 .

\section{DISCUSSION}

The heterogeneity of the sampled environments enabled us to collect 45 Odonata species. Regarding their frequency, 26 of 45 species occurred infrequently (IF), totaling $57.78 \%$, ten species were found very frequently (VF), comprising 1765 collected specimens, and nine species were considered frequent (F) (Table 1).

Regarding genus diversity, De Figueiredo et al. (2013) found 34 Odonata genera in the Rio Ibicuí river basin in Central RS. Their results were higher than the results obtained in this study, which was conducted in the Southern region of the state. However, inferior diversity wealth in this region may be due to insufficient studies. In addition, the huge fields 
of the Pampa Biome, permeated with small forest areas and several types of water bodies, are ideal environments for Odonata (Maluf, 2000).

The UFPel Campus, located in Capão do Leão city, exhibited 42 species, the greatest diversity among all collection sites. Furthermore, Capão do Leão was also where the highest number of insects were captured (579) (Table 1). These data indicate that, despite flow of people in the university campus, the sampling area, that is far away, provide adequate conditions for the Odonata diversity found in the present study. In Rio Grande, the greatest diversity was observed in Arroio Bolaxa, with 34 collected species, while at the Taim Ecologic Station 31 species were observed. The difference in total species found in Arroio Bolaxa and in Taim, may have occurred because of the larger green area exhibited in the first (Juen \& De Marco, 2012). Contraringly to diversity, 161 more specimens were collected at Taim Ecologic Station than in Arroio Bolaxa.

According to the Shannon-Wiener index $\left(\mathrm{H}^{\prime}\right)$, the lowest diversity was found in Pelotas (Table 3). This may be attributed the fact that the collection sites in this city constantly suffer human disturbances, which, according to Clausnitzer \& Jödicke (2004), occur when industrial and/or domestic effluents are inadequately disposed, i.e. in locations close to urban areas. This describes Vila Princesa, an area located near the BR116 road. Human disturbances are also found in the Balneário dos Prazeres collection site, which exhibits large flow of people, such as residents and bathers. The impacts caused on Odonata diversity by human actions in these areas are still unclear, especially because these types of studies are rare in Brazil (Ferreira-Peruquetti \& De Marco, 2002; Clausnitzer et al., 2009). In Pelotas, although lower species diversity was found, its Chao 1 index was higher than Capão do Leão and Rio Grande, estimating 48.6 species. This difference may be because the latter index considers rare species, i.e. it analyzes the number of species represented by only one specimen and the number of species represented by only two sample specimens.
Dragonflies are outstanding insects that can be affected both by environmental (Juen \& De Marco, 2011) and spacial factors (Juen, Cabette, \& De Marco, 2007; Clausnitzer et al., 2009). This indicates that these insects are potential bioindicators for monitoring the quality of aquatic environments (Ferreira-Peruquetti \& De Marco, 2002). Furthermore, dragonflies may be considered valuable tools of freshwater environments, since the diversity of immature Odonata in the environment elucidates the diversity of the entire macroinvertebrate community (Foote \& Rice, 2005).

Twenty-six of the 45 collected species were from the Libellulidae family, which can be explained by the fact that most of these specimens are generalist and can be found in many different environments. Like the rest of the Anisoptera suborder, this family exhibits the largest insects of all Odonata, making them more capable of flying and distributing themselves geographically (Kalkman et al., 2008; Juen \& De Marco, 2012).

M. marcella was the most common of this study with 259 captured specimens and is considered VF at $9.66 \%$ frequency. This may be explained by the fact that it is an abundant and generalist specie. In fact, M. marcella is strongly associated with floating vegetation, such as Eichhornia and Pistia, commonly known as water hyacinth and water lettuce, respectively. Dragonflies deposit their eggs on these floating plants (Paulson, 2017) for reproduction, which is in agreement with the sampling environments studied here.

Concerning the species reported for the first time in Rio Grande do Sul state, $P$. complicatus was collected only six times, all of which occurred in the city of Pelotas. $L$. minutus specimens were collected only in Rio Grande and Taim, and all 15 specimens of the Homeoura ambigua were collected in Rio Grande. T. xiphea specimens were present in all the sampling locations, having been most frequent in Rio Grande, totaling 23 individuals. The aforementioned species expanded its geographic distribution since it was previously only found in Paraguay, Argentina and Rio de 
Janeiro (Heckman, 2006). Regarding frequency, all the specimens reported for the first time were classified as IF.

According to Juen et al., (2007), the distributions of some species are limited by physical and ecological factors. Having that in mind, Southern landscape of RS favors the species that are more agile and more capable of dispersion, since the vegetation is composed mainly by open fields. This may explain the low diversity of Zygoptera found during this study, considering that the small forest areas present in this region are mostly spread out and distant from one another. Due to their type of thermoregulation, these small specimens would have trouble taking long flights in open fields (De Marco \& Resende, 2002). In addition, according to Carvalho, Oliveira-Junior, Faria, and Juen (2013), the Zygoptera would have trouble surviving in open spaces exposed to light and heat.

The sampling efficiency reached in this study was around $78 \%$ (Jack 1) of the expected diversity and was far from reaching the asymptote. This shows that the number of existing species in the studied region is larger than the 45 species found in the present study and that more sampling efforts are required in all regions of the state to find the expected diversity.

Although this study presents the Odonata diversity found in a small sample portion of the Pampa Biome in the south of Rio Grande do Sul, the data are still limited. The species herein reported for the first time in the state show that more studies must be conducted so more precise data about the species of the region can be observed. Furthermore, aquatic sampling should be include the collection of immature stages.

In conclusion, Progomphus complicatus, Lestes minutus, Homeoura ambigua, and Tauriphila xiphea were reported for the first time in the State of Rio Grande do Sul. In regard to the Odonata diversity in the Brazilian pampa biome, 45 species were encompassed in 22 genera and the most commonly found genera were Erythrodiplax and Micrathyria. Concerning the occurrence frequency, 26 species were considered infrequent, 9 were frequent, and 10 were very frequent. The city of Capão do Leão exhibited the largest species diversity (wealth), the largest number of collected specimens, and greatest diversity, in comparison to Pelotas and Rio Grande. The Miathyria marcella species represented $9.6 \%$ of all collected libellulidae and was the most abundant species.

Ethical statement: authors declare that they all agree with this publication and made significant contributions; that there is no conflict of interest of any kind; and that we followed all pertinent ethical and legal procedures and requirements. A signed document has been filed in the journal archives.

\section{ACKNOWLEDGMENTS}

This research was supported by the Coordination for the Improvement of Higher Education Personnel (CAPES), National Council for Scientific and Technological Development $(\mathrm{CNPq})$, Foundation for Research Support of the State of Rio Grande do Sul (FAPERGS) and the members of the Ecological Station of TAIM (ESEC of TAIM) for the indispensable colaboration.

\section{RESUMEN}

Diversidad de adultos de Odonata en el Bioma Pampa brasileño. El crecimiento de la humanidad ha traído consigo varios problemas ambientales que han empeorado con el tiempo, incluida la pérdida de biodiversidad de insectos. Varios autores han mencionado especies del orden Odonata como bioindicadores relevantes para evaluar y controlar las condiciones ambientales de lugares específicos. El objetivo principal de este estudio fue realizar un inventario de la diversidad de Odonata en el Bioma Pampa, en la región sur del estado de Rio Grande do Sul, Brasil. El censo de especies se realizó entre noviembre 2014 y octubre 2015. Se recolectaron insectos adultos en las ciudades de Capão do Leão, Pelotas y Rio Grande. Cada área fue visitada nueve veces, totalizando 54 muestreos. Se usaron redes entomológicas para capturar insectos adultos, que luego se mantuvieron en sobres entomológicos. La identificación de los ejemplares se realizó con claves taxonómicas de Lencioni y Heckman. Además, Chao-1, los índices de Shannon-Wiener y Jackknife se asociaron 
con las áreas de muestreo. Durante el censo de especies se recolectó un total de 2680 especímenes de Odonata, que representan 45 especies comprendidas en 22 géneros y seis familias. Las familias Libellulidae y Coenagrionidae se registraron en 60 y $30 \%$ de los especímenes muestreados, seguidos de los Aeshnidae, Calopterygidae, Gomphidae y Lestidae, de presencia reducida. Los géneros Erythrodiplax, Micrathyria e Ischnura se encontraron al menos una vez en todos los sitios visitados. El estudio resultó en el registro por primera vez de las siguientes especies: Progomphus complicatus Selys, Lestes minutus Selys, Homeoura ambigua Ris y Tauriphila xiphea Ris. Estas especies no se informaron previamente en ningún estudio de Odonata en el estado brasileño de Rio Grande do Sul. Con respecto a la diversidad de Odonata en la región sur de Rio Grande do Sul, Libellulidae y Coenagrionidae son las familias más abundantes. Erythrodiplax y Micrathyria son los géneros más comunes. Miathyria marcella representó el $9.6 \%$ de todos los libellulidae recolectados y fue la especie más abundante. La ciudad de Capão do Leão tiene la mayor diversidad de especies (riqueza), la mayor cantidad de especímenes recolectados y la mayor diversidad que Pelotas y Río Grande. Sin embargo, los resultados mostraron que la Odonatofauna en el estado aún es poco conocida, y se necesitan nuevos estudios para describir mejor este grupo en otras regiones.

Palabras clave: Insecta; biodiversidad; Rio Grande do Sul; libélulas; índices de fauna.

\section{REFERENCES}

Bianconi, G. V., Mikich, S. B., \& Pedro, W. A. (2004). Diversidade de morcegos (Mammalia, Chiroptera) em remanescentes florestais do município de Fênix, noroeste do Paraná, Brasil. Revista Brasileira de Zoologia, 21(4), 943-954. Retrieved from http://www. scielo.br/pdf/rbzool/v21n4/22961.pdf

Boldrini, I. I., Ferreira, P. M. A., Andrade, B. O., Schneider, A. A., Setubal, R. B., Trevisan, R., \& Freitas, E. M. (2010) Bioma Pampa: diversidade florística e fisionômica. Porto Alegre, Brasil: Pallotti.

Cardinale, B. J., Duffy, J. E., Gonzalez, A., Hooper, D. U., Perrings, C., Venail, P., ... Naeem, S. (2012). Biodiversity loss and its impact on humanity. Nature, 486, 59-67. Retrieved from https://www.nature.com/articles/nature11148 DOI: http://10.1038/nature11148

Carvalho, F. G., Oliveira-Junior, J. M. B., Faria, A. P. J., \& Juen, L. (2013). Uso da curva abc como método para detectar o efeito de modificação antropogênica sobre assembleia de Odonata (insecta). Interciencia, 38, 516-522. Retrieved from https://www.interciencia. net/wp-content/uploads/2017/12/516-c-JUEN-7.pdf

Carvalho, F. G., Silva-Pinto, N., Oliveira-Júnior, J. M. B., \& Juen, L. (2013). Effects of marginal vegetation removal on Odonata communities. Acta Limnologica Brasiliensia, 25(1), 10-18. Retrieved from http://www.scielo.br/scielo.php?script=sci arttext\&pid=S2179-975X2013000100003 DOI: $10.1590 / \mathrm{S} 2179-975 \mathrm{X} 2013005000013$

Chao, A. (1984). Nonparametric estimation of the number of classes in a population. Scandinavian Journal of Statistics, 11, 265-270. Retrieved from http:// dns2.asia.edu.tw/ ysho/YSHO-English/1000\%20 Taiwan $\% 20$ (Independent)/PDF/Sca\%20J\%20 Sta11,\%20265.pdf

Chao, A. (1987). Estimating the Population Size for Capture-Recapture Data with Unequal Catchability. Biometrics, 43, 783-791. Retrieved from https://www.jstor. org/stable/2531532?seq=1\#page_scan_tab_contents

Clausnitzer, V., \& Jödicke, R. (2004). Guardians of the watershed global status of dragonflies: critical species, threat and conservation. International Journal of Odonatology, 7, 111-430. Retrieved from https:// www.tandfonline.com/DOI/abs/10.1080/13887890.2 004.9748201

Clausnitzer, V., Kalkman, V. J., Ramc, M., Collen, B., Baillie, J. E. M., Bedjanic, M., \& Wilson, K. (2009). Odonata enter the biodiversity crisis debate: the first global assessment of an insect group. Biological Conservation, 142(8), 1864-1869. Retrieved from https:/www.sciencedirect.com/science/ article/pii/S0006320709001621 DOI: 10.1016/j. biocon.2009.03.028

Colwell, R. K. (2012). User's guide to EstimateS. Statistical Estimation of species richness and shared species from samples. Version 9.1.0. Copyright 19942012. Retrieved from http://viceroy.eeb.uconn.edu/ estimates

Costa, J. M. (1971). Contribuição ao conhecimento da fauna odonatológica do município de Santa Maria, Rio Grande do Sul. Atas da Sociedade Biológica Rio de Janeiro, 14, 193-194.

De Figueiredo, N. S. B, Pires, M. M., Davanso, R. C. S., \& Kotzian, C. B. (2013). Diversity of larvae Odonata (Insecta) River Basin Ibicuí, Rio Grande do Sul, Brasil. Ciência e Natura, 35(2), 084-094. Retrieved from https://periodicos.ufsm.br/index.php/ cienciaenatura/article/viewFile/12563/7974 DOI: $10.5902 / 2179-460 \times 833$

De Marco, P., \& Resende, D. C. (2002). Activity patterns and thermoregulation in a tropical dragonfly assemblage. Odonatologica, 31, 129-138. Retrieved from http://natuurtijdschriften.nl/search?identifier $=592390$

Esteves, F. A. (2011). Fundamentos de Limnologia. Rio de Janeiro, Brasil: Interciência.

Ferraz, A. C. P., Gadelha, B. Q., \& Aguiar-Coelho, V. M. (2009). Análise faunística de Calliphoridae (Diptera) da Reserva Biológica do 
Tinguá, Nova Iguaçu, Rio de Janeiro. Revista Brasileira de Entomologia, 53(4), 620-628. Retrieved from http://www.scielo.br/scielo.php?script=sci_artt ext\&pid=S0085-56262009000400012 DOI: 10.1590 / S0085-56262009000400012

Ferreira-Peruquetti, P. S., \& De Marco, Jr. P. (2002). Efeito da alteração ambiental sobre a comunidades de Odonata em riachos de Mata Atlântica de Minas Gerais, Brasil. Revista Brasileira de Zoologia, 19(2), 317327. Retrieved from http://www.scielo.br/pdf/rbzool/ v19n2/v19n2a02

Foote, A. L., \& Rice, C. L. (2005). Odonates as biological indicators of grazing effects on Canadian prairie wetlands. Ecological Entomology, 30, 1-11. Retrieved from https://onlinelibrary.wiley.com/ DOI/abs/10.1111/j.0307-6946.2005.00701.x DOI: 10.1111/j.0307-6946.2005.00701.x

Heckman, C. W. (2006). Encyclopedia of South American aquatic insects: Odonata - Anisoptera. Dordrecht, Netherlands: Springer.

Heckman, C. W. (2008). Encyclopedia of South American aquatic insects: Odonata - Zygoptera. Washington, DC, USA: Springer.

Juen, L., Cabette, H. S. R., \& De Marco, P. J. (2007). Odonate assemblage structure in relation to basin and aquatic habitat structure in Pantanal wetlands. Hydrobiologia, 579, 125-134. Retrieved from https:// link.springer.com/article/10.1007/s10750-006-03956 DOI: $10.1007 / \mathrm{s} 10750-006-0395-6$

Juen, L., \& De Marco, P. J. (2011). Odonate biodiversity in terra-firme forest streamlets in Central Amazonia: on the relative effects of neutral and niche drivers at small geographical extents. Insect Conservation and Diversity, 4, 1-10. Retrieved from https://onlinelibrary.wiley.com/DOI/ abs/10.1111/j.1752-4598.2010.00130.x DOI: 10.1111/j.1752-4598.2010.00130.x

Juen, L., \& De Marco, P. J. (2012). Dragonfly endemism in the Brasilian Amazon: competing hypotheses for biogeographical patterns. Biodiversity and Conservation, 21(13), 3507-3521. Retrieved from https:// link.springer.com/article/10.1007/s10531-012-03770 DOI: $10.1007 / \mathrm{s} 10531-012-0377-0$

Kalkman, V. J., Clausnitzer, V., Dijkstra, K. D. B., Orr, A. G., Paulson, D. R., \& Tol, J. V. (2008). Global diversity of dragonflies (Odonata) in freshwater. Hydrobiologia, 595, 351-363. Retrieved from https://link. springer.com/article/10.1007/s10750-007-9029-x DOI: $10.1007 / \mathrm{s} 10750-007-9029-\mathrm{x}$

Kittel, R. N., \& Engels, W. (2014). Diversity of damselflies (Odonata: Zygoptera) of the state of Rio Grande do Sul, Brasil, with four new records for the state. Notulae Odonatologicae, 8(3), 49-55. Retrieved from https://www.researchgate.net/ publication/262766709_Diversity_of_damselflies_
Odonata_Zygoptera_of_the_state_Rio_Grande_do Sul_Brasil_with_four_new_records_for_the_state

Lencioni, F. A. A. (2005). Damselflies of Brasil: an illustrated identification guide 1 - non-Coenagrionidae families. São Paulo, Brasil: All Print Editora.

Lencioni, F. A. A. (2006). Damselflies of Brasil: an illustrated identification guide, Volume 2 -Coenagrionidae. São Paulo, Brasil: All Print Editora.

Lutinski, J. A., \& Garcia, F. R. M. (2005). Análise faunística de Formicidae (Hymenoptera: Apocrita) em ecossistema degradado no município de Chapecó, SC. Biotemas, 18(2), 73-86. Retrieved from https://periodicos.ufsc.br/index.php/biotemas/article/view/21413. DOI: $10.5007 / \% 25 \mathrm{x}$

Mace, G. M., Collar, N. J., Gaston, K. J., Hilton-Taylor, C., Akcakaya, H. R., Leader-Williams, N., ... Stuart, S. N. (2008). Quantification of extinction risk: IUCN's system for classifying threatened species. Conservation Biology, 22, 1424-1442. Retrieved from https:// www.ncbi.nlm.nih.gov/pubmed/18847444 DOI: 10.1111/j.1523-1739.2008.01044.x

Maluf, J. R. T. (2000). Nova classificação climática do estado do Rio Grande do Sul. Revista Brasileira de Agrometeorologia, 8, 141-150.

Merritt, R., \& Cummins, K. (1996). An introduction to aquatic insects of North America. Dubuque, USA: Hunt Publishing Company.

Monteiro-Júnior, C. S., Couceiro, S. R. M., Hamada, N., \& Juen, L. (2013). Effect of vegetation removal for road building on richness and composition of Odonata communities in Amazonia, Brasil. International Journal of Odonatology, 16, 135-144. Retrieved from https:// www.tandfonline.com/DOI/abs/10.1080/13887890.2 013.764798 DOI: 10.1080/13887890.2013.764798

Neiss, U. G., \& Hamada, N. (2014). Insetos aquáticos na Amazônia Brasileira: taxonomia, biologia e ecologia. Manaus. Brasil: Editora INPA.

Palmer, M. W. (1991). Estimating species richness: The second-order jackknife reconsidered. Ecology, 72, 1512-1513. Retrieved from https://esajournals.onlinelibrary.wiley.com/DOI/abs/10.2307/1941127. DOI: $10.2307 / 1941127$

Paulson, D. R. (2017). Miathyria marcella. Lista Vermelha da IUCN de Espécies Ameaçadas. e.T165066A80685834. Retrieved from 10.2305/ IUCN.UK.2017-3.RLTS.T165066A80685834.en

Pielou, E. C. (1975). Ecological diversity. New York, USA: John Wiley \& Sons, Inc.

Reaka-Kudla, M. L., Wilson, D. E., \& Wilson, O. (1997). Biodiversity II. Washington, DC, USA: Joseph Henry Press. 
Rehn, A. C. (2003). Phylogenetic analysis of higher-level relationshipps of Odonata. Systematic Entomology, 28, 181-239. Retrieved from https://onlinelibrary.wiley. com/DOI/abs/10.1046/j.1365-3113.2003.00210.x DOI: $10.1046 / \mathrm{j} .1365-3113.2003 .00210 . x$

Renner, S., Périco, E., Sahlén, G., Dos Santos, D. M., \& Consatti, G. (2015). Dragonflies. (Odonata) from the Taquari River valley region, Rio Grande do Sul, Brasil. Check List, 11(5), 1740. Retrieved from https:// www.biotaxa.org/cl/article/view/11.5.1740 DOI: 10.15560/11.5.1740

Silva, D. P., Marco, P., \& Resende, D. C. (2010). Adult odonate abundance and community assemblage measures as indicators of stream ecological integrity: a case study. Ecological Indicators, 10(3), 744-752. Retrieved from https://www.sciencedirect.com/science/article/pii/S1470160X09002039 DOI: 10.1016/j. ecolind.2009.12.004

Silveira Neto, S., Nakana, O., Barbin D., \& Vila Nova, N. A. (1976). Manual de ecologia dos insetos. Ouro Fino, Brasil: Editora Agronômica Ceres.

Teixeira, M. C. (1971). Contribuição para o conhecimento da fauna odonatológica do Rio Grande do Sul.
Arquivos do Museu Nacional (Rio de Janeiro), 54, 17-24.

Trindade, C. R. T., Furlanetto, L. M., \& Silva, C. P. (2009). Nycthemeral cycles and seasonal variation of limnological factores of a subtropical shallow lake (Rio Grande, RS, Brasil). Acta Limnologica Brasiliensia, 21, 34-44. Retrieved from http://repositorio.furg.br/bitstream/handle/1/117/ Nycthemeral $\% 20$ cycles $\% 20$ and $\% 20$ seasonal $\% 20$ variation $\% 20$ of $\% 201$ imnological $\% 20$ factors $\% 20$ of $\% 20$ a $\% 20$ subtropical $\% 20$ shallow $\% 201$ ake $\% 20$ $\% 28$ Rio $\% 20$ Grande $\% 2$ C $\% 20$ RS $\% 2$ C $\% 20$ Brasil\%29.pdf?sequence $=1$

Trueman, J. W. H., \& Rowe, R. J. (2009). Odonata. Dragonflies and damselflies. The Tree of Life Web Project. Electronic Database. Retrieved from http:// tolweb.org/Odonata/8266/2009.10.16

Zambrano, L., Contreras, V., Hiriart, M. M., \& Arista, A. E. Z. (2009). Spatial heterogeneity of water quality in a highly degraded tropical freshwater ecosystem. Environmental Management, 43(2), 249-263. Retrieved from https://www.ncbi.nlm.nih.gov/pubmed/18941831 DOI: 10.1007/s00267-008-9216-1 